\title{
Surficial sediments of the Paraná Inner Continental Shelf, Southern Brazil
}

\author{
Luiz Henrique Sielski $^{\text {ac }}$, Rodolfo José Angulo ${ }^{\text {bd }}$, Maria Cristina Souza ${ }^{\text {be }}$, Fernando Alvim \\ Veiga $^{\text {bf }}$
}

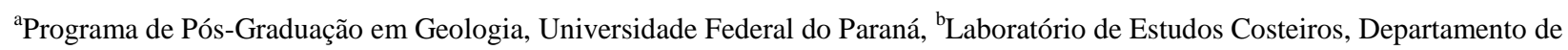
Geologia, Universidade Federal do Paraná

cluizion@gmail.com, ${ }^{\mathrm{d}}$ fitoangulo@gmail.com, ${ }^{\mathrm{e}}$ cristinasouza2527@gmail.com, ${ }^{\mathrm{f}}$ fernandoalvimveiga@gmail.com

\begin{abstract}
This study examines surficial sediment distribution patterns, slope and morphological characteristics of the Paraná inner continental shelf. Paraná inner continental shelf is located on the southern Brazilian continental shelf, a wide and low gradient shelf, in the vicinity of two large unfilled estuaries and the Serra do Mar mountain range. It is characterized as a wave/storm dominated continental shelf with microtidal, semidiurnal regime and a small supply of recent continental sediments. We analyzed grainsize parameters and sediment composition of 875 grab samples and investigated the inner continental shelf morphology and slope through a digital bathymetric model built from regional nautical charts. We combined and evaluated the characteristics of grain-size curves, the spatial distribution of sediments, and the morphology and slope of the inner continental shelf to identify different sedimentary facies. Sediment distribution patterns change from the coast seaward and between three defined sectors along the coastline: south, central and north inner continental shelf. This variation seems to be related to recent sediment sources and to the presence of deposits from ancient coastal plain and inner continental shelf environments formed before the last Holocene sea-level highstand. Sediments with mean diameter of fine to very fine sands prevail at all depths. Deposits of sediments with mean diameter of silt and medium to coarse sands are significant in particular areas, generally associated with steep slopes, troughs, and sand ridges. Possible causes of sedimentary patchiness are the outcropping of medium to coarse sand and the supply of recent estuarine muddy sediments provided by large estuarine complexes to the Paraná inner continental shelf. The results obtained contribute to the knowledge about the sediment dynamics of Paraná inner continental shelf.
\end{abstract}

Keywords: sedimentology; grain-size distribution curves; sand ridges; sand and mud outcrops; stratigraphic window.

\section{Introduction}

The Paraná inner continental shelf (PICS) is located between $25^{\circ} 58^{\prime}$ and $25^{\circ} 19^{\prime} \mathrm{S}$, at the Southern Brazilian Continental Shelf. The sedimentary cover of the PICS is practically unknown. It was partially described in previous large-scale surveys projects such as REMAC (Global Reconnaissance of the Brazilian Continental Margin), and REVIZEE (Living Resources in the Exclusive Economic Zone) and some regional studies carried at the PICS (Veiga et al. 2004, Sielski 2015). Despite expected bottom sediments homogeneity observed on small-scale charts $(1: 1,100,000)$ (see Milliman \& Barreto 1975, Zembruski 1979, Figueiredo \& Tessler 2004), the PICS has a complex distribution of sedimentary patches, with the mean diameter of sediments varying from coarse sand to silt (Veiga et al. 2004). This contrast could be primarily related to the sample grid size and sampling density, in which higher density or smaller grids produce more detailed information than the opposite. Furthermore, fine sediments input from large estuaries and palimpsest sediments occurrences may contribute to this sedimentary complexity (Veiga et al. 2004).
Almost 60 to $80 \%$ of coastal regions of the world present some sediment heterogeneity (Holland \& Elmore 2008). Most of the studies regarding inner continental shelves correlate the pattern of sediment distribution to the exposure to waves and currents, the sediment sources and the depth gradient (e.g. Rosa et al. 2013). Nevertheless, much emphasis is given to present day processes whilst the fundamental role of antecedent geology is underestimated Dominguez et al. (2013) highlight that in the narrow, shallow and low accumulation central Brazilian continental shelf, mud depocenters are formed firstly due to the availability of accommodation space on depressions associated with large unfilled incision valleys and secondly due to the processes such as wave and tidal regime. In addition, the preceding substrate can act as a source of sediments as the surficial sediments erode. Masselink \& Lessa (1995) suggest that on the central Queensland inner continental shelf, southeastern Australia, transgressive estuarine mud underlying a regressive barrier outcrops as stratigraphic windows.

Sediment supply, transport, and reworking are determinant processes to continental shelf sediments spatial distribution. Over time, these processes can be triggered or interrupted. The interrelation of these 
processes and their period of action, past or present, can be used to classify continental shelf sedimentary deposits (McManus 1975). Sediments supplied at the present will constitute a deposit that differs from another formed by sediments supplied in the past. Furthermore, those deposits may be reworked by the action of waves and currents changing their structure and composition. If finer sediments were added to a coarser deposit or vice-versa then high heterogeneity is expected. If sediments are being reworked, then they tend to become more homogeneous as the processes responsible for reworking persists over time.

Rivers and estuaries are the primary supply paths for continental sediments to the continental shelf. Rivers with high bottom velocities flows may supply sand, while those with lower velocities may provide mud. Sand particles commonly accumulate near river mouths, forming deltas under the influence of waves (Anthony 2015). In regions where the input of mud is significant, sandy shelves may act as a repository for recent muddy sediments (Crocket \& Nittrouer 2004). The presence of mud can attenuate wave action (Calliari et al. 2001, Sheremet et al. 2005) and interfere with sediment disposal. On the Rio Grande do Sul coast, southern Brazil, sediments from muddy banks may reach the beach after being remobilized by storm events (Calliari et al. 2007). Either, the action of waves may cause fluidization of cohesive mud (Chou et al. 1991) which may be the case of outcropping muds on inner continental shelves like Queensland, Australia.

This work aims to characterize the bottom sediments composition and spatial distribution, attempting to understand the causes of sedimentary patchiness on the PICS. Causes of sediment distribution are discussed, possible sediment sources and the factors influencing sediment transport paths and deposition. Particular attention is given to grain-size distribution curves to determine distinct sedimentary facies.

\section{Regional setting}

The PICS is located in the central part of Southern Brazilian continental shelf. It is characterized by its width, of $230 \mathrm{~km}$, and a gentle slope, of around 1:1,300. The continental shelf break is located around $180 \mathrm{~m}$ depth (Mahiques et al. 2010). The PICS area is of 3,000 $\mathrm{km}^{2}$ between 5 and $30 \mathrm{~m}$ isobaths (figure 1). The tidal regime is microtidal, semidiurnal, with an average range of $1.4 \mathrm{~m}$ in the open sea (Marone \& Jamiyanaa 1997). The main direction of wave propagation on the PICS is from SSE and SE, associated with the action of subtropical cyclones, with significant wave height of 0.5 to $1.5 \mathrm{~m}$ and period of 6 to 9 seconds (Nemes \& Marone 2013). Maximum values of significant wave height and period can reach $7.3 \mathrm{~m}$ and $15 \mathrm{~s}$ on the continental shelf break (Pianca et al. 2010) and $5 \mathrm{~m}$ and $17 \mathrm{~s}$ near the coast (Nemes \& Marone 2013).

The coastal region adjacent to the PICS is marked by the presence of a mountain range named the Serra do Mar and extensive Quaternary coastal plains. The coastal plains are up to $55 \mathrm{~km}$ wide, constituted of mainly Holocene and Pleistocene regressive barriers and sandy beaches that form a total of $126 \mathrm{~km}$ of shoreline extent (Angulo \& Araujo 1996, Lessa et al. 2000, Angulo et al. 2000, 2006). The mid- to late-Holocene coastal progradation occurred due to a combination of the falling sea-level $(\sim 3 \mathrm{~m})$ and a positive sedimentary budget, which increases from south to north. Southernmost Holocene coastal plain, located at Barra Velha $\left(25^{\circ} 39^{\prime} \mathrm{S}\right)$, is only few hundred meters wide increasing northward up to $5 \mathrm{~km}$ at Paranaguá $\left(25^{\circ} 34^{\prime} \mathrm{S}\right)$ (Lessa et al. 2000). Paraná coastal barriers distinguish from other regressive barriers described in the literature by the presence of high content of fine sediments with vegetal debris and a predominance of swalley cross stratification in lower and middle shoreface (Souza et al. 2012). The occurrence of fine sediments and organic matter is also evident in the central sector of the PICS (Veiga et al. 2006). The coastal zone is characterized by the presence of the estuarine complexes, Paranaguá and Guaratuba, which receive flows of a catchment area of $\sim 3.9 \times 10^{3} \mathrm{~km}^{2}$ and $\sim 1.9 \times 10^{3} \mathrm{~km}^{2}$ respectively (Angulo 1992). Estuaries remained infilled at the same time of the mid to late-Holocene coastal progradation, due to lowering sea level (Angulo et al. 2009). The catchment areas of Paranaguá and Guaratuba basins are characterized by high-gradient incised rivers flowing onto a low-gradient floodplain with rivers, estuarine head-deltas and estuaries located in the coastal plain (Angulo et al. 2016). Other small and filled estuaries, like the Saí-Guaçu and Matinhos rivers, flows directly to the ocean. The sandy beaches of Paraná are composed mainly of well-sorted sands with a mean diameter of medium to very fine sand and generally with low contents of heavy minerals and bioclasts (Angulo et al. 2016).

The sources of sediments to the PICS are not well known. Most of the fluvial sand and coarser sediments supply is trapped at the head of estuary deltas (Lessa et al. 2000), and part of fine sediments are released to the continental shelf through estuarine complexes (Veiga et al. 2006, Angulo et al. 2009). However, the sandy material could be transported to the continental shelf by estuaries main tidal channels and smaller estuaries of Saí-Guaçu and Matinhos rivers (Angulo et al. 2016). The lack of significant fluvial sediment supply, contrasting with large coastal barriers, suggests that coastline accretion has been driven by longshore drift currents carrying sediments eroded from other coastal barriers, as the Barra Velha, southward from PICS (Lessa et al. 2000). The first sources of sediments to the PICS and Paraná coastal environments are the Archean to Phanerozoic rocks from where sediment particles were eroded. During Quaternary time $(\sim 2.6 \mathrm{Ma})$, these sediments were transported, reworked and redistributed following the sea-level changes (Angulo et al. 2016). From the last glacial maximum $(\sim 20 \mathrm{ka})$, sediments provided from Archean to Phanerozoic rocks were laid where the present shelf is. Numerous transgressive/regressive cycles during the Quaternary have reworked these sediments several times, resulting 
in mature polycyclic beach sediments at the coast (Angulo et al. 2016) and at the continental shelf.

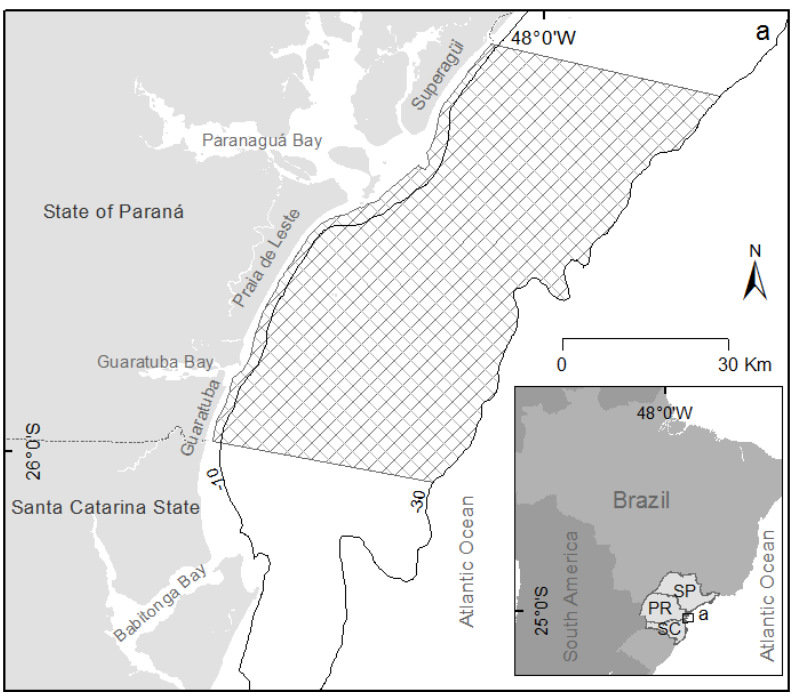

Figure 1: PICS location, crosshatch area. Dashed lines represents interstate limits between the states of Paraná - PR, São Paulo - SP and Santa Catarina - SC. Solid lines, 10 and 30 meters isobaths.

On small scale $(1: 1,100,000)$, sediments covering southeastern Brazilian continental shelf in Paraná latitude vary from fine sand to mud. The mean grain size apparently decreases seaward, and the transition zone from very fine sand to mud occurs in approximately $100 \mathrm{~m}$ deep (see Figueiredo \& Tessler 2004). On larger scale $(1: 500,000)$ charts, fine sands are predominant with some occurrences of medium to coarse sand associated with oblique sand ridges, and very fine sand, with mud content between 10 to $40 \%$, related to estuarine supply (Veiga et al. 2004, 2006). Fine sediments also occur at depths of 14 to 16 meters under a $30 \mathrm{~cm}$ thick sand layer below the seabed. These sediments were identified as Pleistocene paleoestuarine muds (Veiga et al. 2006).

\section{Methods}

It was used a dataset of 875 sediment samples collected along past decades in different research projects, in various scales and with different sampling grids along the PICS (for details see Veiga et al. 2004, Sielski 2015). All samples were obtained with a grab sampler between the isobaths of 5 and $30 \mathrm{~m}$. Besides the differences in survey scales and sample grids, all projects adopted regularly spaced grids with spacing varying between 0.5 to 2 nautical miles (NM). Near the coast, surveys were carried with sampling grids between 0.5 and $1 \mathrm{NM}$ and, at deeper areas, between 10 and 30 m depth, with a grid of $2 \mathrm{NM}$ (figure 2). Methods for grain size analysis were common to all datasets and were performed by sieving for fractions from sand to gravel $(>0,063 \mathrm{~mm})$ (Folk 1965) and by the pipette method for fine-grained fractions $(<0,063 \mathrm{~mm})$ (Carver 1971). Carbonate content was obtained by acid leaching (Milliman 1974). Organic matter content was quantified by weight loss on ignition (Davies 1974). Raw data from sieving and pipetting was reanalyzed to standardize sediment grain-size statistics. The grain-size parameters were calculated by the method of moments on the statistical package GRADISTAT v. 8.0 (Blott \& Pye 2001) following the classification of Folk \& Ward (1957) and granulometric scale of Wentworth (1922). The curves of grain-size distribution were obtained from the histograms. The curves were used to analyze multiple data at the same graphic and visually distinguish similar types of sediments.

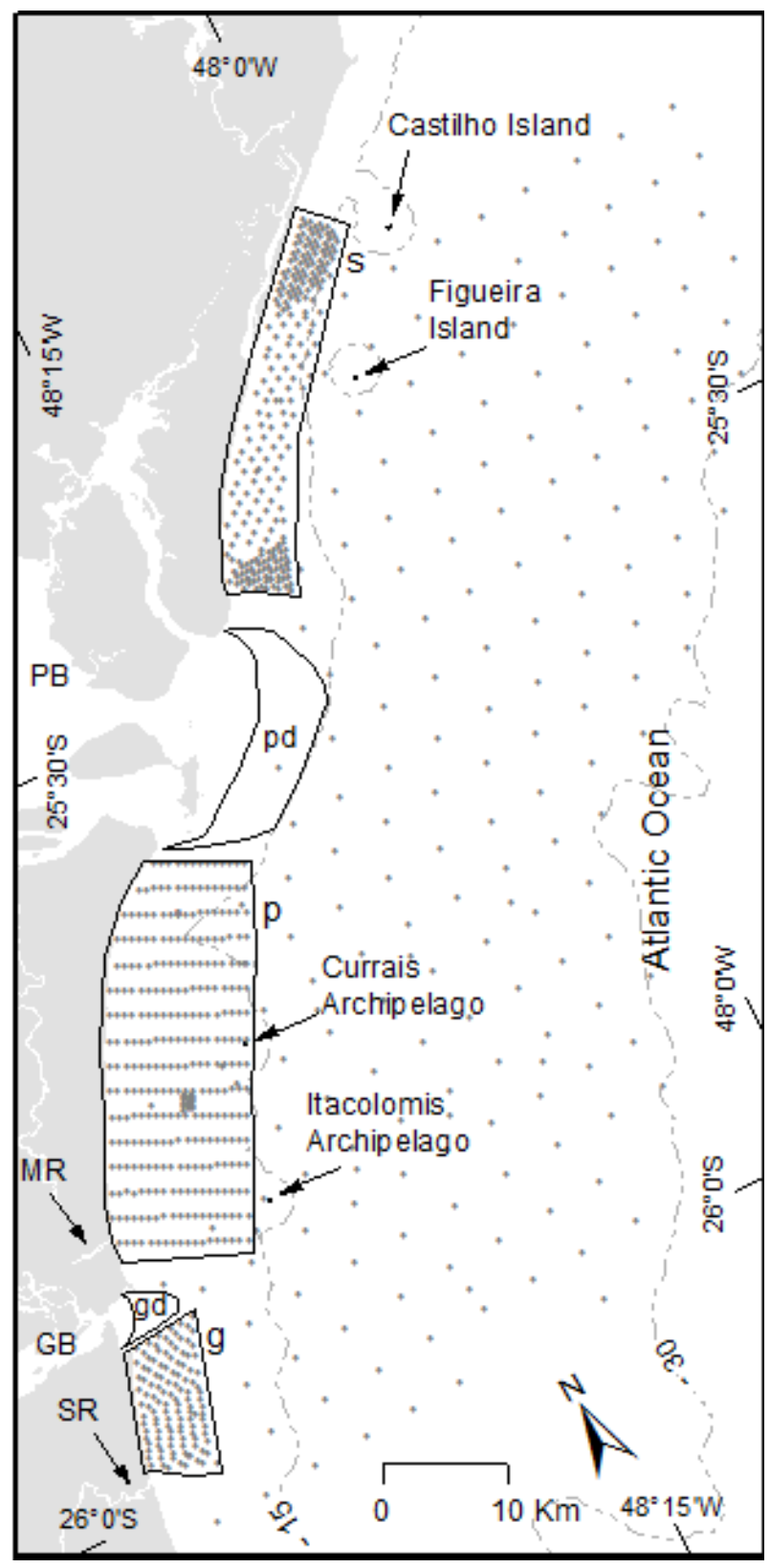

Figure 2: Sediment sampling grid, gray dots; (g) Guaratuba sector, (p) Praia de Leste sector, (s) Superagüi sector; (gd) Guaratuba delta, (SR) Saí River, (MR) Matinhos River; (GB) Guaratuba Bay, (PB) Paranaguá Bay, (pd) Paranaguá delta. Isobaths in meters, dotted lines.

Morphology and slopes were interpreted based on a digital bathymetric model obtained by linear interpolation spline (Franke 1982) of bathymetric data. The grid resolution was of $100 \mathrm{~m}$. This method produces a smooth surface that passes exactly trough the bathymetric points, and it was developed to deal with scattered data. Spline was used at this work due to the 
characteristics of the interpolation in predicting ridges and valleys, in representing a smoothly varying surface, as it is the PICS, and due to the nature of scattered bathymetric data on nautical charts. Bathymetric data used in the model was extracted from the electronic nautical charts 1830 scale $1: 89,459 ; 1803$ scale $1: 25,000 ; 1820$ scale $1: 100,000$ and 1821 scale $1: 25,000$ of the Brazilian Navy. The PICS slope was calculated as the relationship between the vertical elevation (v) and the corresponding distance $(\mathrm{h})$ expressed in degrees by the tangent of $\mathrm{v} / \mathrm{h}$ for each cell of the bathymetric model. Troughs and ridges were identified in longitudinal bathymetric profiles over the digital bathymetric model.

Sedimentary facies were identified through the analysis of grain size statistical parameters related to measures of central tendency, dispersion, and asymmetry, and the sediments spatial distribution in relation to the morphological features and slope of the PICS. For instance, well-sorted fine to very fine sands occurs near the coast presenting a particular pattern of grain-size distribution curves, being its occurrence associated to shoreface steep slope gradient. On the other hand, sands with the same mean diameter, that present different grain-size distribution curves are located seaward in deeper areas of gentle slopes to flat slopes. The sedimentary facies map was obtained by visual aggregation of interpreted sediment points.

\section{Results}

The PICS was divided in one sector between 10 to 30 $\mathrm{m}$ isobaths, comprising all the extension of Paraná coast between the Saí-Guaçu River (South) and the Castilho Island (North), and three sectors, south, central and north, between 5 to $10 \mathrm{~m}$ isobaths. Named: (1) Guaratuba, extending from Saí-Guaçu River to Guaratuba tidal delta; (2) Praia de Leste, from Guaratuba tidal delta to Paranaguá tidal delta; and (3) Superagüi, from Paranaguá tidal delta to Castilho Island.

\subsection{The PICS Morphology and slope}

The PICS presents an almost regular bottom with slopes varying from a marked steep slope at the shoreface to gentle and flat slopes prevailing at deeper areas. Steep slopes were defined as values ranging from $0.35^{\circ}$ to $0.1^{\circ}$, gently slopes as values from $0.1^{\circ}$ to $0.03^{\circ}$ and flat slopes lower than $0.03^{\circ}$ (figure 3). The PICS morphology comprises morphological features such as troughs and ridges. Troughs are present in two scales: smaller troughs ( 0.5 to $2 \mathrm{~km})$ are associated with ridges connected to shoreface, and larger troughs $(>2 \mathrm{~km})$ forms channel-like features in areas deeper than $15 \mathrm{~m}$.

Near the coast steep slopes cover about $170 \mathrm{~km}^{2}$, corresponding to the shoreface. Slope breaks are found near 10 to $15 \mathrm{~m}$ isobaths, representing the boundary between lower shoreface and the transition zone. At sectors of Guaratuba and Praia de Leste, slope breaks are located near $10 \mathrm{~m}$ isobath. At Superaguii, the break is located around $15 \mathrm{~m}$. Steep slopes are also evident at the edge of Paranaguá and Guaratuba tidal deltas and on the flanks of larger (4 to $6 \mathrm{~km}$ ) troughs (figure 4).

Sand ridges fields are found up to $20 \mathrm{~m}$ deep connected to the shoreface and are more evident in Praia de Leste sector. Sand ridges in the PICS are about $2 \mathrm{~m}$ height and $4 \mathrm{~km}$ length (figure 4). Between 20 and 30 $\mathrm{m}$, sand ridges are sparser and can reach up to $6 \mathrm{~km}$ between crests. From the toe of the shoreface until approximately $20 \mathrm{~m}$ deep, flat and gentle slopes are also found with a predominance of gentle slopes. Steep slopes occur around $20 \mathrm{~m}$ isobath forming a discrete line. From around 20 up to $30 \mathrm{~m}$ deep, flat slopes prevail surrounded by gentle slopes and isolated areas of steep slopes.

At Guaratuba, around $10 \mathrm{~m}$ deep, the shoreface slope break strikes in a gentle slope of $0.05^{\circ}$ followed by a flat slope of $0.001^{\circ}$ ending at $12 \mathrm{~m}$ deep. From 15 to $20 \mathrm{~m}$ isobaths, sand ridges occur adjacently to troughs succeeded seaward by a gentle slope with $0.04^{\circ}$. Between 20 and $30 \mathrm{~m}$ deep, sand ridges are sparser. At Praia de Leste, flat slopes are evident with approximately $0.007^{\circ}$ around $10 \mathrm{~m}$ water depth, at the base of the shoreface steep slopes. From the base of flat slope until $16 \mathrm{~m}$ deep steep slopes occur. Gentle slopes predominate between 16 to $23 \mathrm{~m}$ followed by steep slopes until $30 \mathrm{~m}$ water depth. Compared to Guaratuba and Praia de Leste, the Superaguii inner continental shelf is deeper and with the smallest area of sand ridges. A large channel-like trough $(6 \mathrm{~km}$ wide $)$ is placed at the base of the shoreface at Superaguii sector. Between 12 and $20 \mathrm{~m}$ isobaths, steep slopes are evident with $0.12^{\circ}$. Flat slopes occur around the $20 \mathrm{~m}$ isobath followed by a gentle slope at $25 \mathrm{~m}$. 


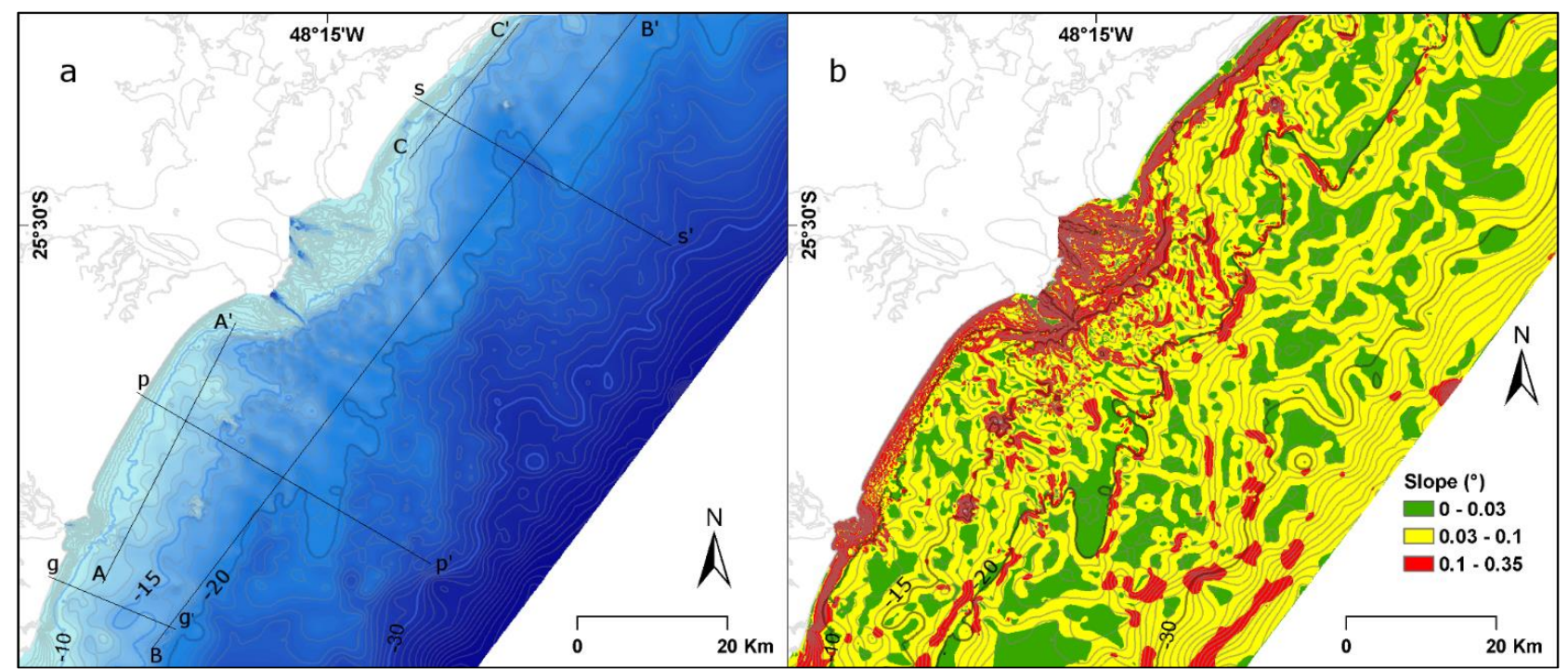

Figure 3: (a) PICS morphology showing the location of bathymetric profiles, and (b) PICS slope gradients.
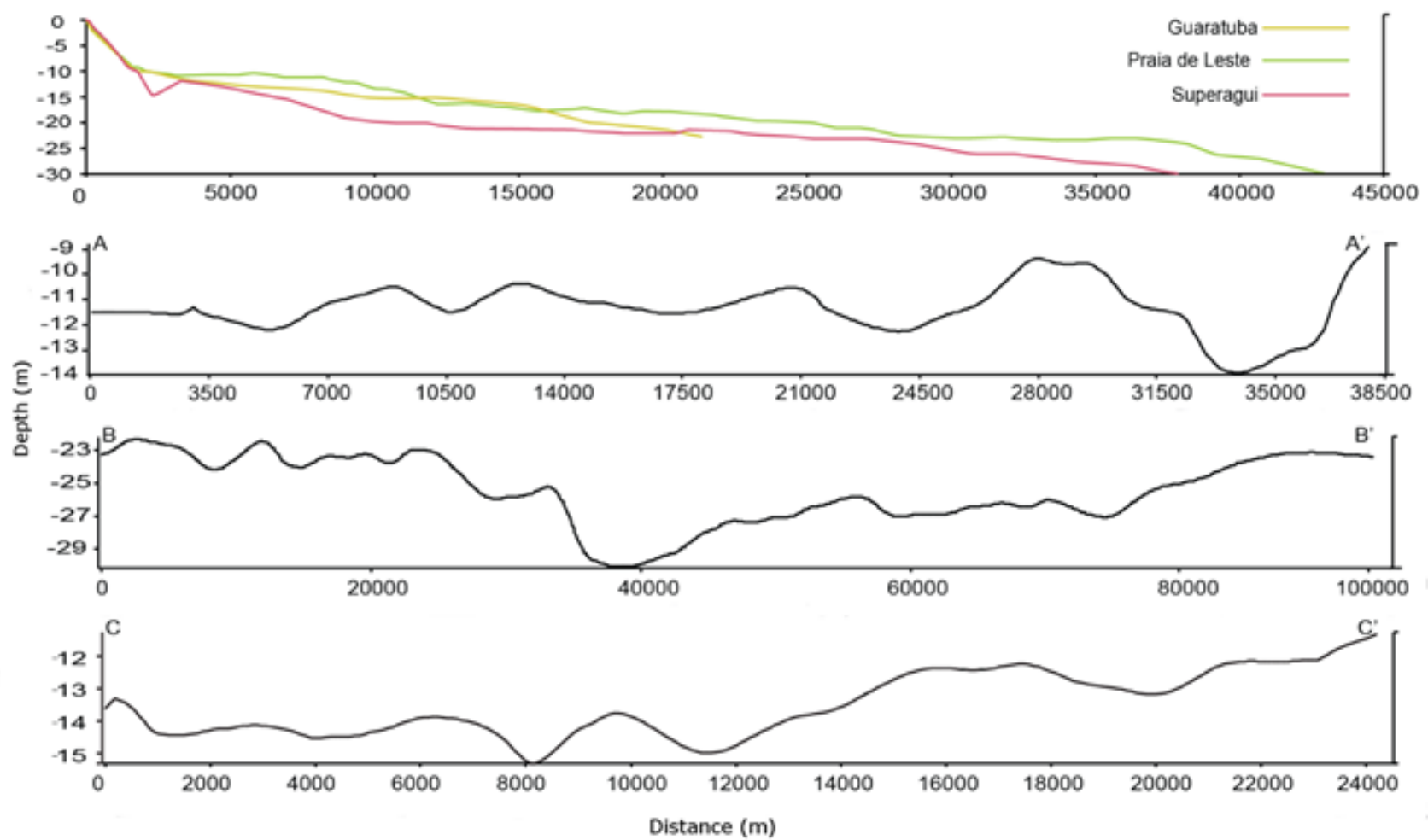

Figure 4: Bathymetric profiles, for location see figure 3a. Guaratuba (g-g'), Praia de Leste, (p-p') and Superagüi (s-s') transversal profiles. A-A', B-B' and $\mathrm{C}-\mathrm{C}^{\prime}$ longitudinal profiles showing the morophology of sand ridges.

\subsection{Sediments characteristics}

Sediments covering the PICS are composed of siliciclastic sand and silt, with the mean diameter varying from 0.016 to $1.032 \mathrm{~mm}$ (figure 5). Sediments with a mean diameter of 0.063 to $0.250 \mathrm{~mm}$ cover $80 \%$ of the inner continental shelf, $53 \%$ are fine and $27 \%$ very fine sand. Most of the samples, $86 \%$, present less than $5 \%$ of organic matter and $75 \%$, less than $5 \%$ of carbonates. The highest rates of organic matter are related to the mud contents on sediments, and the highest carbonate concentrations (10 to $50 \%$ ) are associated with the presence of shells in coarser sediments, with the mean diameter greater than 0.250 mm (figure 6). Near the coast and around oceanic islands sediment is poorly sorted. Sediments are better sorted between 10 and $30 \mathrm{~m}$ isobaths. Skewness prevails between symmetric to strongly fine skewed. The coarse skewed sediments are unimodal fine sands, very well to moderately well sorted (table 1).

\subsection{Grain-size curves analysis}

(1) For sediments with the mean diameter of silt $(0.004-0.063 \mathrm{~mm})$, most of the first mode is found in fractions of very fine and fine sand $(0.075-0.213 \mathrm{~mm})$ and less often on fractions of silt $(0.004-0.046 \mathrm{~mm})$. One sample in Superagüi sector has the first mode on the medium sand, $0.302 \mathrm{~mm}$. The second mode of 
sediments with the mean diameter in silts predominates between silt or very fine to fine sands $(0.004-0.046$ or $0.075-0.213 \mathrm{~mm})$. Two samples have a second mode in 0.302 and $0.853 \mathrm{~mm}$. The sediments are predominantly very well to moderately sorted the bimodal samples are moderately to very poorly sorted.

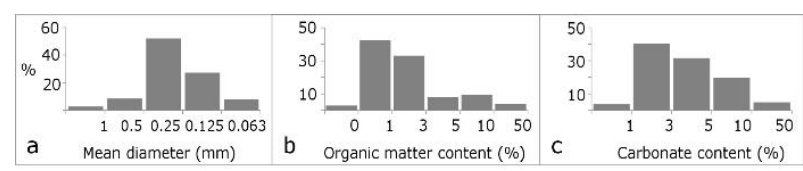

$$
\text { d }
$$

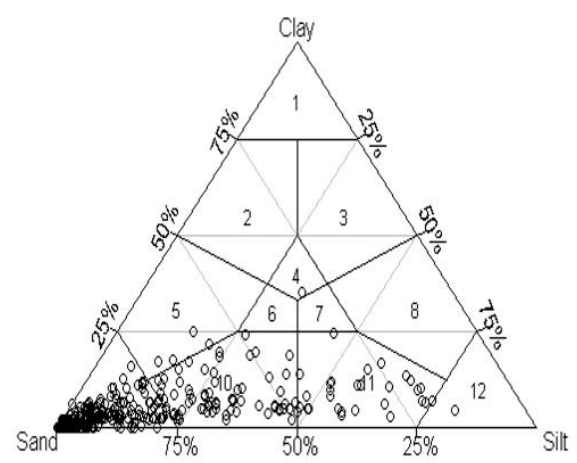

Figure 5: Sediments overview, frequency of (a) mean diameter classes, (b) organic matter content, and (c) carbonate content, (d) Shepard diagram: 1) clay, 2) sandy clay, 3) silty clay, 4) clayey mud, 5) clayey sand, 6) sandy mud, 7) silty mud, 8) clayey silt, 9) sand, 10) silty sand, 11) sandy silt, 12) silt.

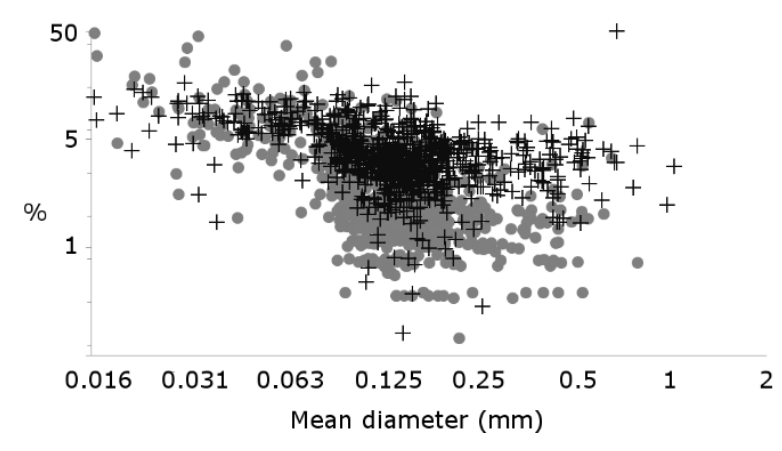

Figure 6: Contents of carbonates, black crosses, and organic matter, gray dots, in relation to mean grain size.

(2) The unimodal very fine sand (mean diameter of 0.063-0.125 mm) exhibit predominating mode between fine and very fine sand classes $(0.075-0.213 \mathrm{~mm})$. Some occurrences present modes in the class of medium sand $(0.213-0.302 \mathrm{~mm})$ and coarse sand $(0.853 \mathrm{~mm})$. Unimodal very fine sands are moderately well to very well sorted and coarse skewed. The bimodal sediments with the mean diameter of very fine sand present the first mode between fine and very fine sand classes $(0.075-0.213 \mathrm{~mm})$. Three bimodal samples have the first mode in medium sand class $0.302 \mathrm{~mm}$ and one in coarse sand $0.854 \mathrm{~mm}$. The second mode predominates in silt classes $(0.003$ and $0.046 \mathrm{~mm})$ with few occurrences in the very fine sand and medium sand classes $(0.075 \mathrm{~mm}$ and $0.427 \mathrm{~mm})$. The bimodal very fine sands are characterized as moderately to very poorly sorted, and skewness prevails among symmetric to very fine skewed.

(3) Sediments with the mean diameter of fine sand $(0.125-0.250 \mathbf{~ m m})$ have unimodal distributions with modes in fine sand class $(0.106-0.214 \mathrm{~mm})$. Only $5 \%$ of sediments with the mean diameter of fine sand presents the mode in medium sand class $(0.302-0.427$ $\mathrm{mm})$. Sediment sorting prevails from well sorted to moderately sorted. In general, sorting is related to the occurrence of fractions smaller than $0.063 \mathrm{~mm}$ so that the samples classified as poorly to very poorly sorted present mud contents between 10 and $40 \%$. Samples with the best sorting have medium sand content above $20 \%$ or very fine sand content above $30 \%$ accompanied by coarse or fine skewness measures.

(4) The sediments with the mean diameter of medium sands $(\mathbf{0 . 2 5 0}-\mathbf{0 . 5 0 0} \mathbf{~ m m})$ show mostly unimodal distribution at the medium sand fraction $(0.302-0.427 \mathrm{~mm})$. The bimodal samples present the second mode between very fine and coarse sand classes $(0.075-0.603 \mathrm{~mm})$. These sediments are well sorted with prevailing skewness towards the fine. Bimodal medium sands are characterized as moderately well to poorly sorted. Some medium sands with coarse sand content around $20 \%$ are coarse skewed.

Table 1: General grain-size statistics of sediments.

\begin{tabular}{|c|c|c|c|c|c|}
\hline Mean diameter & Mode & 1st mode & 2nd mode & Sorting & Skewness \\
\hline $\begin{array}{l}\text { (1) Silt }(0.014- \\
0.063 \mathrm{~mm})\end{array}$ & $\begin{array}{l}\text { Bimodal - } \\
\text { polymodal }\end{array}$ & $\begin{array}{l}\text { Silt - fine sand }(0.004- \\
0.213 \mathrm{~mm}) \text { and medium } \\
\text { sand }(0.302 \mathrm{~mm})\end{array}$ & $\begin{array}{l}\text { Silt }(0.004-0.047 \mathrm{~mm}), \text { fine to } \\
\text { very fine sand }(0.075-0.213 \mathrm{~mm}) \\
\text { and medium sand }(0.427 \mathrm{~mm})\end{array}$ & $\begin{array}{l}\text { Poorly - very poorly } \\
\text { sorted }\end{array}$ & Fine skewed \\
\hline $\begin{array}{l}\text { (2) Very fine } \\
\text { sand }(0.063- \\
0.125 \mathrm{~mm})\end{array}$ & $\begin{array}{l}\text { Unimodal - } \\
\text { bimodal }\end{array}$ & $\begin{array}{l}\text { Very fine }- \text { coarse sand } \\
(0.075-0.853 \mathrm{~mm})\end{array}$ & $\begin{array}{l}\text { Silt }(0.003-0.047 \mathrm{~mm}) \text {, very fine } \\
\text { sand }(0.075 \mathrm{~mm}) \text { and medium sand } \\
(0.427 \mathrm{~mm})\end{array}$ & $\begin{array}{l}\text { Moderately - very } \\
\text { well sorted }\end{array}$ & $\begin{array}{l}\text { Symmetric to } \\
\text { very fine } \\
\text { skewed }\end{array}$ \\
\hline $\begin{array}{l}\text { (3) Fine sand } \\
(0.125-0.250 \\
\mathrm{mm})\end{array}$ & Unimodal & $\begin{array}{l}\text { Very fine to medium sand } \\
(0.106-0.427 \mathrm{~mm})\end{array}$ & 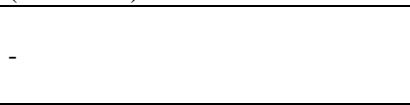 & $\begin{array}{l}\text { Moderately - very } \\
\text { well sorted }\end{array}$ & $\begin{array}{l}\text { Fine skewed } \\
\text { - coarse } \\
\text { skewed }\end{array}$ \\
\hline $\begin{array}{l}\text { (4) Medium } \\
\text { sand }(0.250- \\
0.500 \mathrm{~mm})\end{array}$ & $\begin{array}{l}\text { Unimodal - } \\
\text { bimodal }\end{array}$ & $\begin{array}{l}\text { Medium sand }(0.302- \\
0.427 \mathrm{~mm})\end{array}$ & $\begin{array}{l}\text { Very fine to medium sand }(0.075- \\
0.603 \mathrm{~mm})\end{array}$ & $\begin{array}{l}\text { Moderately - very } \\
\text { well sorted }\end{array}$ & $\begin{array}{l}\text { Symmetric- } \\
\text { fine skewed }\end{array}$ \\
\hline $\begin{array}{l}\text { (5) Coarse to } \\
\text { very coarse sand } \\
(0.500-2.000 \\
\mathrm{mm})\end{array}$ & $\begin{array}{l}\text { Unimodal - } \\
\text { bimodal }\end{array}$ & $\begin{array}{l}\text { Medium to very coarse } \\
\text { sand }(0.427-1.205 \mathrm{~mm})\end{array}$ & $\begin{array}{l}\text { Medium to very coarse sand }(0.302 \\
-1.705 \mathrm{~mm})\end{array}$ & $\begin{array}{l}\text { Well to very well } \\
\text { sorted }\end{array}$ & $\begin{array}{l}\text { Symmetric to } \\
\text { fine skewed }\end{array}$ \\
\hline
\end{tabular}


(5) The sediments with the mean diameter of coarse and very coarse sand have unimodal and bimodal distributions. For unimodal distribution, mode values are between medium to coarse sand fractions $(0.427-1.205 \mathrm{~mm})$. The bimodal distributions present the first mode between medium to coarse sand classes $(0.302-0.854 \mathrm{~mm})$ and the second mode occurs from medium to very coarse sand fractions (0.302 $1.705 \mathrm{~mm}$ ). Both unimodal and bimodal are classified as moderately well to well sorted. The skewness is predominantly symmetrical. Coarse sands with positive skewness present the first mode between 0.603 and $0.853 \mathrm{~mm}$.

\subsection{Sediments spatial distribution}

Fine-grained sediment, with mean diameter between 0.016 and $0.063 \mathrm{~mm}$, occur from 5 to $15 \mathrm{~m}$ deep and are composed of silts and very fine sands with mud contents between 10 and $40 \%$. The width of the distribution of fine sediments is greater in Superaguii sector, up to $15 \mathrm{~m}$ deep, and up to $10 \mathrm{~m}$ in the southwest portion of Guaratuba sector. Sediments present sand contents higher than $90 \%$ at depths greater than $10 \mathrm{~m}$. The medium to coarse sand $(0.250$ to $1.00 \mathrm{~mm})$ presents a patchy distribution between 10 and $30 \mathrm{~m}$ isobaths with the highest concentration in Guaratuba and Praia de Leste, south and central sectors respectively (figure 7).

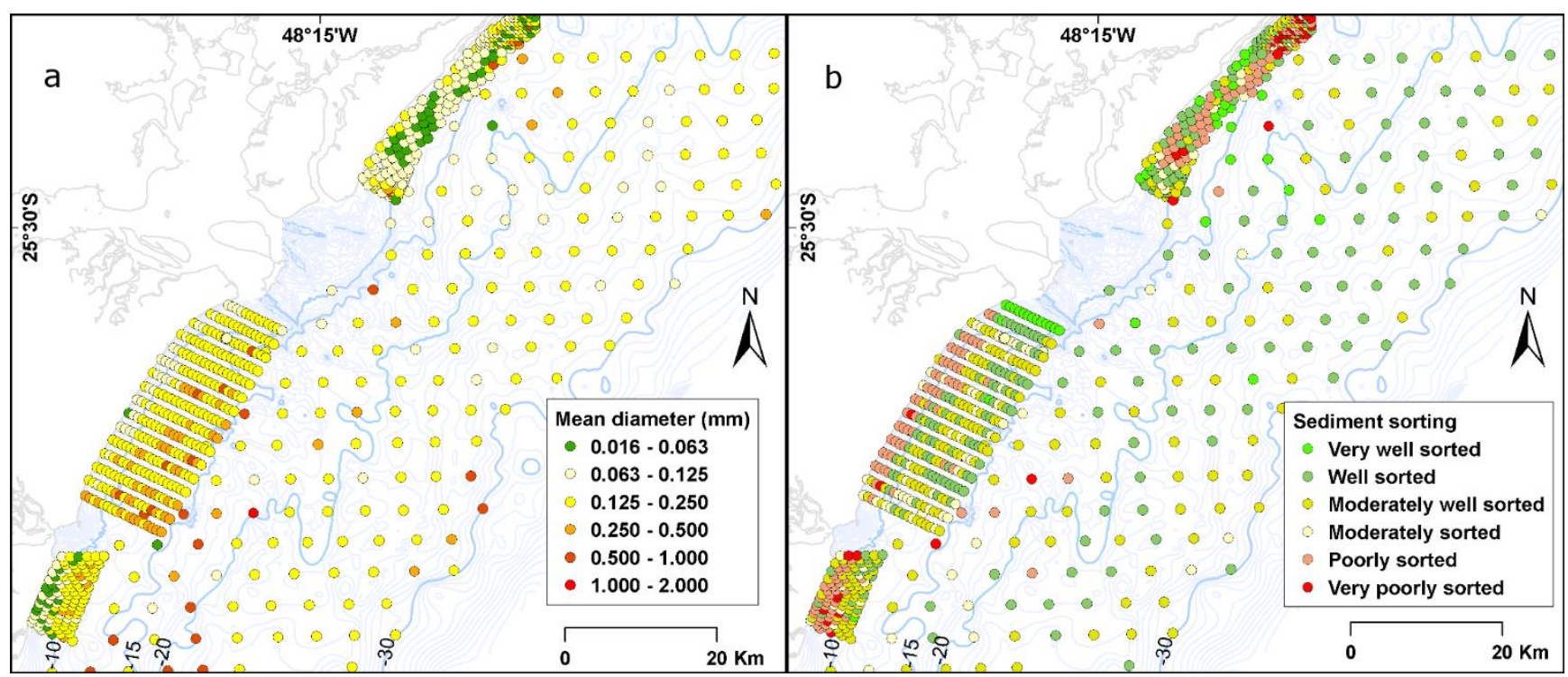

Figure 7: (a) mean diameter and (b) sediment sorting of PICS sediments.

Moderately to well-sorted sediments covers most of the area between 10 and $30 \mathrm{~m}$ deep except around the oceanic islands (Figueira, Currais, and Itacolomis) and the Paranaguá tidal delta where they are very poorly to moderately sorted. In shallower areas, up to $10 \mathrm{~m}$ water depth in Guaratuba and Praia de Leste sectors and up to $15 \mathrm{~m}$ deep in Superagüi, the sediments are predominantly very poorly to poorly sorted (figure 7). Poorly to very poorly sorted sediments have a longitudinal distribution, whereas well to moderately well sorted sediments are widely distributed between 10 and $30 \mathrm{~m}$, and longitudinally distributed near the coast, between 5 and $10 \mathrm{~m}$ depths.

In general, the very fine to coarse sands, with mean diameter from 0.063 to $1.000 \mathrm{~mm}$, are moderately to very well sorted. Of these, part of the sands with the mean diameter between 0.063 and $0.250 \mathrm{~mm}$ are moderately sorted. The silts and some occurrences of fine to very fine sand, with mean diameter from 0.016 to $0.250 \mathrm{~mm}$, are very poorly to moderately sorted (figure $8)$.

\subsection{Sedimentary facies}

It was possible to distinguish sediment types by similarities of grain-size distribution curves. The sediments are related to each other in accordance with its spatial distribution, resulting in five sedimentary

facies (table 2). These facies were determined based on grain size parameters, on the spatial distribution, morphology and slope gradients of the inner continental shelf. For example, the well-sorted fine and very fine sand are different from sediments with the same mean diameter but with poorer sorting degree.

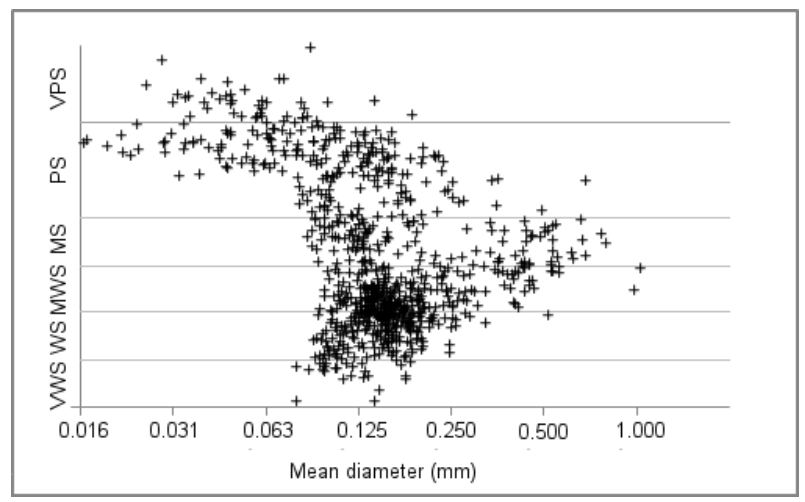

Figure 8: Relation of mean diameter and sediment sorting. VWS very well sorted, MS - moderately sorted, PS - poorly sorted, VPS very poorly sorted.

The mean diameter seems to be influenced by the distribution of sediments in the modal classes and around the first mode, followed by measures of coarse or fine skewness. Sediments with the mean diameter in silt, with the first mode on classes of fine and very fine 
sand, and mud content from 10 to $40 \%$ are coarse skewed. Otherwise, medium sands with the first mode in fine to very fine sand are fine skewed. Mud content showed strong negative correlation with sorting for the very fine sands. Sediments with the mean diameter of very fine sands have considerable contents of silt and fine sand classes, greater than $20 \%$. Contents of silt and fine sand are correlated with the mean diameter between 0.063 and $0.125 \mathrm{~mm}$. In other words, some sediments classified by mean diameter as very fine sands have high contents of silt, and so, different distribution curves from those with higher content of fine sands. The same is true for contents of medium sand and very fine sand, which are correlated to mean diameters of fine sand between 0.125 and $0.250 \mathrm{~mm}$. Fine to very fine sands presents different grain-size distribution curves between the shoreface and deeper regions of the shelf.

Table 2: Sedimentary facies characteristics

\begin{tabular}{|c|c|c|}
\hline Sedimentary facies & Sediments grain-size characteristics based on distribution curves & Spatial distribution \\
\hline \multirow{2}{*}{$\begin{array}{l}\text { (1) Shoreface well- } \\
\text { sorted very fine sands } \\
\text { facies }\end{array}$} & $\begin{array}{l}\text { Moderately to well sorted very fine sands, symmetrical to coarse skewed, mesokurtic } \\
\text { to very leptokurtic }\end{array}$ & \multirow{2}{*}{$\begin{array}{l}\text { Longitudinal to the shore up to, } \\
\text { approximately, } 10 \mathrm{~m} \text { water depth }\end{array}$} \\
\hline & $\begin{array}{l}\text { Moderately to well sorted fine sands with contents of } 20 \text { to } 60 \% \text { of medium sand, } \\
\text { with very leptokurtic and very fine skewed distribution curves }\end{array}$ & \\
\hline (2) Muddy facies & $\begin{array}{l}\text { Bimodal silts poorly to very poorly sorted with platykurtic symmetrical to very fine } \\
\text { skewed }\end{array}$ & $\begin{array}{l}\text { Longitudinal and shore oblique } \\
\text { between } 5 \text { to } 10 \mathrm{~m} \text { water depth } \\
\text { and in isolated areas from } 10 \text { to } 19 \\
\mathrm{~m} \text { water depth }\end{array}$ \\
\hline \multirow{2}{*}{ (3) Muddy sands facies } & $\begin{array}{l}\text { Poorly to very poorly sorted very fine sands, with bimodal distribution, very fine } \\
\text { skewed, leptokurtic to very leptokurtic and with mud contents higher than } 10 \%\end{array}$ & \multirow{2}{*}{$\begin{array}{l}\text { Longitudinal to the shore up to, } \\
\text { approximately, } 15 \mathrm{~m} \text { water and in } \\
\text { isolated areas from } 15 \text { to } 29 \mathrm{~m} \\
\text { water depth }\end{array}$} \\
\hline & $\begin{array}{l}\text { Moderately to poorly sorted fine sands with mud contents between } 10 \text { to } 40 \% \text {, } \\
\text { leptokurtic and coarse skewed distribution curves }\end{array}$ & \\
\hline \multirow{2}{*}{$\begin{array}{l}\text { (4) Inner continental } \\
\text { shelf sands facies }\end{array}$} & $\begin{array}{l}\text { Moderately well to well sorted very fine sands approximately symmetrical and } \\
\text { mesokurtic distribution curves }\end{array}$ & \multirow{2}{*}{$\begin{array}{l}\text { Widely distributed from } 10 \text { to } 30 \\
\text { m water depth }\end{array}$} \\
\hline & $\begin{array}{l}\text { Very fine sands with modes of } 0.107 \mathrm{~mm} \text {, more than } 30 \% \text { of fine sand contents and } \\
\text { coarse skewed distribution curves }\end{array}$ & \\
\hline \multirow{2}{*}{$\begin{array}{l}\text { (5) Medium to coarse } \\
\text { sands facies }\end{array}$} & $\begin{array}{l}\text { Moderately sorted medium sands with leptokurtic and coarse skewed distribution } \\
\text { curves }\end{array}$ & \multirow{2}{*}{$\begin{array}{l}\text { In isolated areas from } 10 \text { to } 30 \mathrm{~m} \\
\text { water depth }\end{array}$} \\
\hline & $\begin{array}{l}\text { Coarse to very coarse sands moderately sorted with mesokurtic, symmetrical to fine } \\
\text { skewed distribution }\end{array}$ & \\
\hline
\end{tabular}

(1) Shoreface well-sorted very fine sands facies occurs seaward from the surf zone and may reach the depth of slope break at the toe of shoreface. Composed of sand with the mean diameter between fine and very fine sand, with a predominance of very fine sand. These sediments are well sorted and have approximately symmetrical and leptokurtic distribution curves (figure 9a). This facies is characteristic of high-energy environments and associated with the steep slopes of the shoreface.

(2) Muddy facies - characterized by sediments with the mean diameter of coarse to fine silt, poorly sorted, with skewness tending to coarse and mainly with two or more modes (figure 9b). These sediments are concentrated between 5 and $14 \mathrm{~m}$ depth in the region of medium to lower shoreface but can occur in isolated areas between 14 and $20 \mathrm{~m}$ depths. The modes are distributed between fine silt and fine sand (0.004 to $0.213 \mathrm{~mm}$ ). Some of these sediments, with contents of medium to coarse sand between 10 and $25 \%$ and mean diameter greater $0.250 \mathrm{~mm}$, are concentrated at Superaguii, between 13 and $15 \mathrm{~m}$, associated with surrounding coarser sediments. The characteristics of these sediments: poorly sorted, with bimodal platykurtic distributions and skewness predominantly positive suggest that there is a mixture of at least two populations of sediments between medium sands and silts. Muddy sediments are associated with depressions such as troughs between sand ridges.

(3) Muddy sands facies - composed of bimodal sediments with the mean diameter of very fine sand and mud contents from 10 to $40 \%$, and poorly sorted fine sand with 5 to $35 \%$ of mud contents (figure 9c). Muddy sands are concentrated between 5 and $15 \mathrm{~m}$ deep forming large contiguous areas longitudinally or obliquely to the coastline and in isolated areas between 15 and $30 \mathrm{~m}$. This facies is spatially related with muddy facies.

(4) Inner continental shelf sands facies - presents sediments with the mean diameter of fine to very fine sand well sorted symmetrical to coarse skewed. This facies is widely distributed between 10 and $30 \mathrm{~m}$ isobaths, except in Superagüi sector where this pattern has a narrower distribution between 15 and $30 \mathrm{~m}$ isobaths. Sediments of this facies differ from the shoreface facies due to the predominance of fine sand in a manner that sediments with the mean diameter of very fine sand here present fine sand contents between 10 and $40 \%$ (figure 9d). This facies occurs in deeper regions seaward the breaking slope of shoreface.

(5) Medium to coarse sands facies - presents sediments with a mean diameter of 0.250 to $1.032 \mathrm{~mm}$ and modes predominating between 0.302 and $1.205 \mathrm{~mm}$ (figure 9e). This facies occurs in isolated areas of the PICS from 5 to $30 \mathrm{~m}$ water depth, it is more frequent at Praia de Leste, but occur widely in the other sectors near steep slopes and sand ridges fields. 


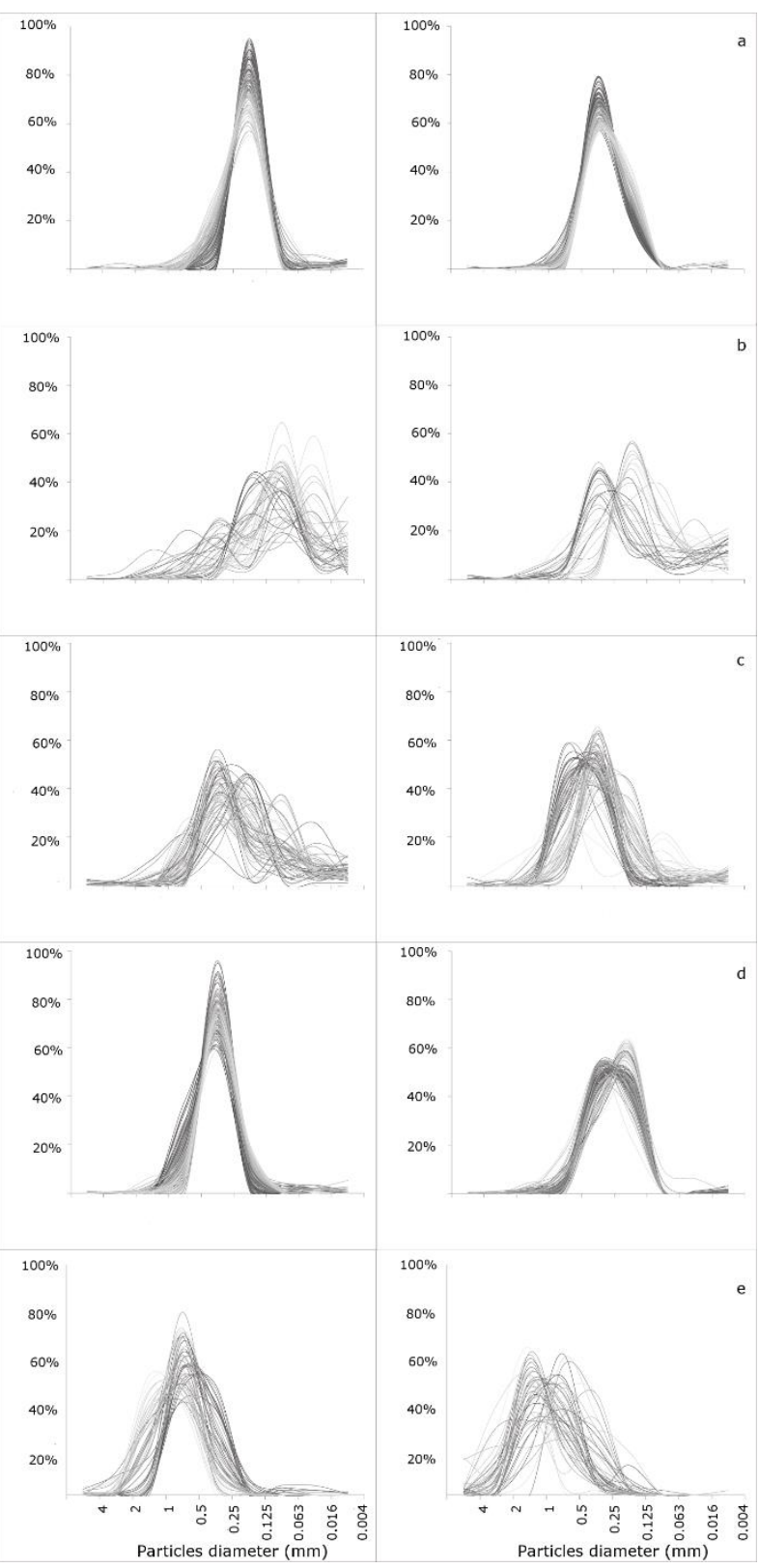

Figure 9: Grain-size distribution curves of: a) shoreface well-sorted very fine sands, b) muddy sediments, c) muddy sands, d) inner continental shelf sands, and e) medium to coarse sands.

There is a marked zonation from the base of surf zone up to $30 \mathrm{~m}$ water depth (figure 10). Seaward the base of the surf zone, the shoreface well-sorted very fine sands facies predominates. The muddy facies borders the shoreface well-sorted very fine sands facies seaward followed by muddy sands facies at the lower shoreface until $15 \mathrm{~m}$ water depth. From the zone between 10 and $12 \mathrm{~m}$ to $30 \mathrm{~m}$ water depth inner continental shelf sands facies predominate with several isolated areas of medium to coarse sand. This pattern of sediment distribution is typical, with some distinction, in the three sectors of the PICS. The shoreface well-sorted very fine sands facies covers $64 \mathrm{~km}^{2}$ of $174 \mathrm{~km}^{2}$ of the shoreface along the PICS. This facies can reach up to $14 \mathrm{~m}$ depth at Superagüi and to $10 \mathrm{~m}$ depth at Guaratuba sector, while at Praia de Leste it is restricted to the uppermost regions near the base of the surf zone. The muddy facies covers a total area of $37 \mathrm{~km}^{2}$ and the most extensive areas occur in Superagüi, $28 \mathrm{~km}^{2}$ against $8 \mathrm{~km}^{2}$ in Guaratuba and less than $1 \mathrm{~km}^{2}$ in Praia de Leste. On the other hand, the muddy sands, inner continental shelf sands and medium to coarse sand facies occupy a proportionately larger area in Praia de Leste than in other sectors.

\section{Discussion}

Sediments spatial distribution in the PICS show significant differences from the early models described in the literature where the grain size tends to decrease seaward (e.g. Johnson 1919). Instead, a sedimentary patchiness, typical of present-day continental shelves (Suter 2006) is evident in the three sectors of the PICS. Very fine sands are found in the shoreface interspersed with muddy sediments. Several areas of medium to coarse sands are distributed offshore. While facies (1), (2) and (3) predominate near the shore, on an environment characteristically dominated by the action of waves, facies (4) and (5) concentrate seaward in areas with a predominance of storm waves. In the latitude of Sate of Paraná, the transition zone from sand to mud is only evident around $100 \mathrm{~m}$ water depth as seen in smallscale charts (e.g. Figueredo \& Tessler 2004). The depth where this transition occurs suggests a larger hydrodynamic energy and thus a wider extension of the inner continental shelf, mainly driven by storm waves. It is estimated that storm waves can agitate the continental shelf seabed from the shore to approximately 60 to $80 \mathrm{~m}$ water depth assuming a periods of $11 \mathrm{~s}$, frequent for the area (Pianca et al. 2010, Nemes \& Marone 2013), and using the equation to derive wavelength from wave period, as proposed by Xu et al. (1999).

The seabed between the base of the surf zone and the $30 \mathrm{~m}$ water depth is often subject to wave action, $85 \%$ of the time (Nemes \& Marone 2013), even though finegrained sediments occur in shallow water, between 5 and $15 \mathrm{~m}$ deep. The concentration of fine sediments in shallow and low gradient continental shelves of coasts dominated by waves or storms is something controversial. The deposition and imprisonment of these sediments depend partly on the input of high rates of suspended sediments in addition to the characteristics of the trajectory and mixture of plumes (Wright 2012). Gravitational flows and inshore transport components are also essential for the maintenance of fine sediments near the coast (Wright 1995). Oceanographic conditions capable of trapping sediments in the shoreface may be achieved on the Paraná coast with fair-weather waves and low intensity coastal currents, which may favor the mud settlement after flocculation in estuarine plume fronts. However, to form and preserve mud deposits, high rates of sediment input are needed. Moreover, the frequency of storms and swell characteristics (see Pianca et al. 2010, Nemes \& Marone 2013) are enough to remove recently settled sediments. In fact, wave regime on the Paraná coast causes considerable volumetric variations at the sand beaches. The greatest volumetric variation of sediments registered in Paraná 
beaches occur in autumn and spring (Quadros et al. 2007) and coincide with the pattern of swell waves, more frequent during this period (Nemes \& Marone 2013). The inner continental shelf of the South of Rio Grande do Sul, is one example of the capacity of waves to mobilize fine-grained sediments. These sediments supplied by Patos Lagoon to the inner continental shelf can reach the beach after storm events (Calliari et al. 2007). Despite the similarities of both Paraná and south of Rio Grande do Sul inner continental shelves, such as the wave regime and the gentle slope, there is no report of mud reaching the beaches on the Paraná coast. It is possible to speculate that the PICS receives lesser amounts of fine sediments, which are temporarily retained at the inner shelf, the wave action may rework these sediments keeping it suspended in the water column.
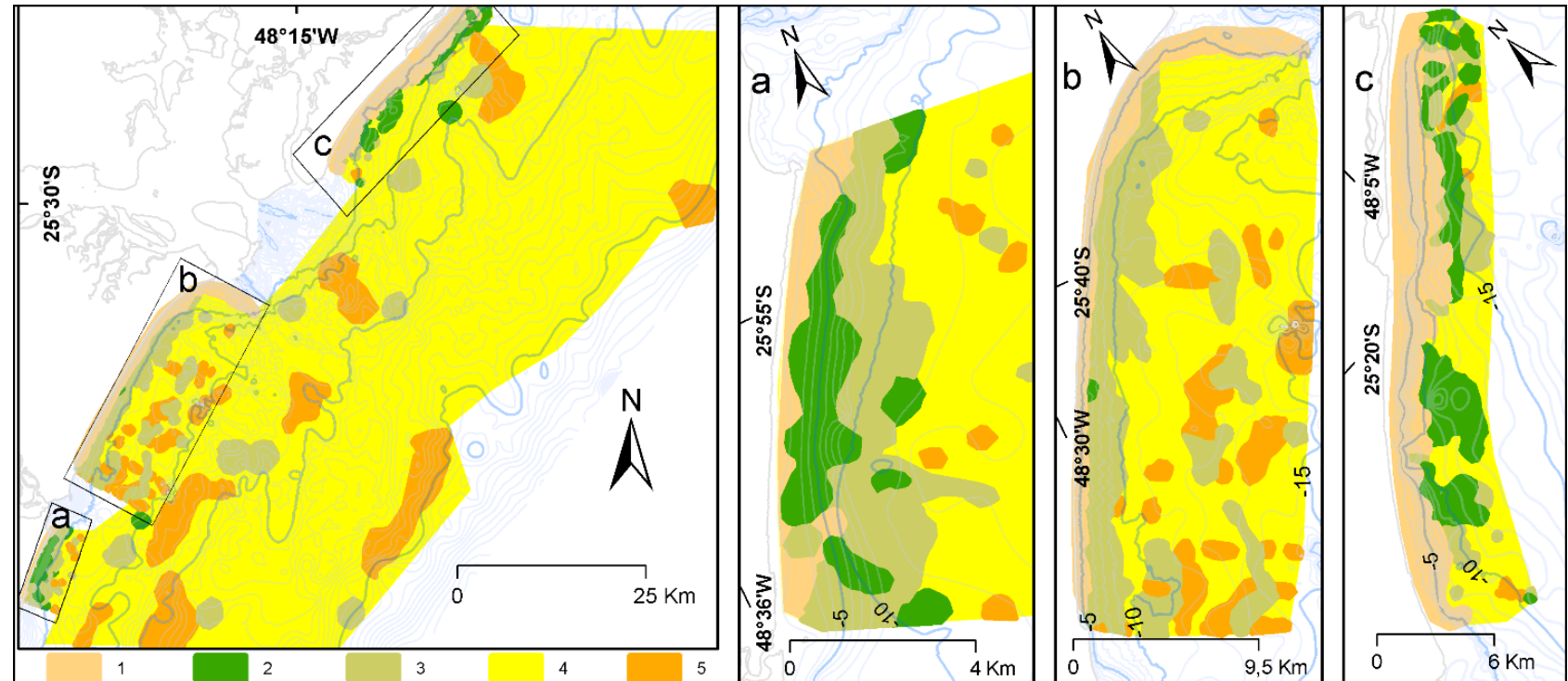

Figure 10: PICS map of sedimentary facies. 1) Shoreface well-sorted very fine sands facies, 2) Muddy facies, 3) Muddy sands facies, 4) Inner continental shelf sands facies, 5) Medium to coarse sands facies.

Based on the pattern and nature of fine-grained sediment accumulation in continental margins, Walsh \& Nittrouer (2009) proposed a classification of these systems. The authors classify the systems as dominated by estuarine accumulation, by marine dispersion, by proximal accumulation, by capture in submarine canyons or as subaqueous delta clinoform. The most significant systems to deliver fine sediments to continental shelves are the proximal accumulation dominated systems. These occur mostly where riverine sediment inputs are very high, in order of tens to thousand Mt/yr., examples are the Mississippi and Yellow rivers continental shelves (DeMaster et al. 1985, Coleman et al. 1998). Sediment export rates by the estuarine systems to the PICS are unknown but are certainly lower than the rates of rivers flowing to continental shelves classified as proximal accumulation dominated. The sediment export rates can be estimated to a maximum of $2 \mathrm{Mt} / \mathrm{yr}$, which would classify the PICS as the estuarine accumulation system proposed by Walsh \& Nittrouer (2009). It can be said that most of the fine sediments accumulate inside the unfilled estuaries. However, some fractions of fine-grained sediment may escape through estuarine plumes and flocculate in the estuarine plume front rapidly settling in order of few tens of kilometers from the estuary mouths. Waves and longitudinal currents may act in dispersing fine-grained sediments supplied to the PICS by redistributing these sediments longitudinally in a patchy pattern, adding characteristics of marine dispersal dominated systems.
Veiga et al. (2006) relate the occurrence of muddy and muddy sands facies with high rates of organic matter in the middle and lower shoreface to recent sediments supplied by estuarine plumes off to the PICS. Another path of fine-grained sediments may be the transport under hyperpycnal flows. Modeled distribution of suspended sediment concentration at the mouth of Paranaguá bay is higher at bottom layers than is at the top layer, suggesting more effective transport near the seabed (Mayerle et al. 2015). In the present study, it was found a relatively extensive area of fine sediments distributed on the shoreface, including shallow regions near the base of the surf zone. This area covers around $14 \%$ of Guaratuba and $21 \%$ of Superagüi sectors (see figure 10). The difference in the proportion of muddy facies between the three sectors may suggest that large estuarine complexes downstream of longitudinal currents are the sources of fine sediments to the PICS. Larger estuaries, with higher export rates, supply the sectors with the largest area of fine sediments. Muddy facies occupy $8 \mathrm{~km}^{2}$ at the Guaratuba sector, which sediments may be supplied by the Babitonga bay, less than $1 \mathrm{~km}^{2}$ at Praia de Leste sector, provided by the Guaratuba bay, and $28 \mathrm{~km}^{2}$ at the Superagüi sector, supplied by the Paranaguá bay. Nevertheless, a qualitative analysis of satellite images of the PICS suggests that plumes of Babitonga bay are frequently deflected to NE, hardly reaching Guaratuba inner continental shelf sector (NASA Worldview http://go.nasa.gov/1ReMSDf). If these sediments settle southward Guaratuba, one possible path of transport 
would be the longshore currents, although they would have more chance to be resuspended and dispersed in the water column than to accumulate in isolated areas of the shoreface.

Another source of fine-grained sediments to the PICS would be the ancient sedimentary facies underlying present-day inner continental shelf deposits. The suggestion that the occurrence of stratigraphic windows in the PICS is quite possible for some reasons. Firstly, due to the thickness of Holocene continental shelf deposits and the Holocene evolution of coastal barriers in the PICS area, secondly due to the wave and currents energy of deeper areas, typically $30 \mathrm{~m}$, as evidenced by the presence of coarser sediments in deeper regions, a typical feature of storm-dominated continental shelves. Veiga et al. (2006) suggest that the reworking of inner continental shelf sediments by the action of waves and storms promotes the erosion of surface layers of sediments, exposing older sediment deposits in the PICS. The antecedent geology may perform a fundamental role in inner continental shelves. As noticed by Dominguez et al. (2013) in the narrow, shallow and low accumulation continental shelf of central Brazil, mud depocenters form primarily due to the accommodation space of depressions associated with the antecedent geology of large unfilled incision valleys with the wave and tidal regime being latter. In Bucasia, central Queensland, Australia, Masselink \& Lessa (1995) suggest that transgressive estuarine mud occurs under regressive barrier deposits outcrops in the present-day inner continental shelf.

In the evolution model of the Paraná coastal plain, proposed by Lessa et al. (2000), the Holocene regressive barrier is described over paleo lagoon sediments between $6 \pm 2$ and $14 \pm 2$ m below mean sea level. This paleo lagoon could correspond to the muddy sediments outcropping in the inner continental shelf. However, subsequent studies dismissed the occurrence of paleo lagoon sediments when interpreted fine sediments underlying Holocene regressive sand bodies as Pleistocene inner continental shelf deposits (Souza et al. 2012). The organic matter and plant debris rich sediments in the regressive barrier of Praia de Leste were interpreted as inner continental shelf and middle shoreface facies deposited around the same period of the formation of the regressive barrier and its origin is related to the supply by large estuarine complexes (Souza et al. 2012). Nevertheless, the barrier clinoforms downlap on top of transgressive surface eroded in the Pleistocene inner continental shelf muddy sediments (Souza et al. 2012). The larger concentration of fine sediments in Guaratuba and Superagüi sectors may be related with their barriers evolution. The barriers of Superaguii and Guaratuba show distinct characteristics from that of Praia de Leste. While back-barrier paleoestuarine deposits are found on the Praia de Leste region, the same is not present on Superaguii and Guaratuba regions. Pleistocene and Holocene barriers on Superaguii are in direct contact (Angulo et al. 2009). It is supposed that paleo-estuarine deposits could be found bellow the Superagüi regressive barrier deposits and outcropping in some areas of the PICS northern sector. A similar setting could be present at Guaratuba.

One significant finding made by Veiga et al. (2006) is that Pleistocene sediments occur under a thin layer, 20 $80 \mathrm{~cm}$, of Holocene fine to coarse sands. This low thickness of Holocene substrate is a result of low sediment input and high hydrodynamic energy. Organic mud content found in a $50 \mathrm{~cm}$ thick core, in a region where muddy sands facies occur at $8 \mathrm{~m}$ water depth, were dated, giving ages from 1,517 - 1,189 $\mathrm{BP}{ }^{1{ }^{4} \mathrm{C}}$ associated to inner continental shelf foraminifera assemblages (Veiga et al. 2006). Further, another two samples located at 14 and $16 \mathrm{~m}$ depth, under a 20 to 80 $\mathrm{cm}$ sand layer were dated as Pleistocene $(40,600$ $+2,250 /-1,750$ and $46,700+5,800 /-3,350{ }^{14} \mathrm{C}$ years B.P respectively) (Veiga et al. 2006). The thickness of present inner continental shelf facies suggests that low rates or none sediments were delivered to this environment during the last sea level transgressive/regressive cycle.

It seems that the inner continental shelf is an important source of sediments to Paraná sandy beaches. As noticed by Souza et al. (2012) this has been the primary source of sediments to beaches since the Holocene sea level highstand (Souza et al. 2012). At the outer part of the ebb tidal channel of Paranaguá Bay, transverse tidal currents have high energy with velocities around $75 \mathrm{~cm} / \mathrm{s}$, longshore currents up to 18 $\mathrm{cm} / \mathrm{s}$, and the transport of bottom sediments is mainly northward (Noernberg et al. 2007). Bottom currents velocities at the central region of the PICS in $10 \mathrm{~m}$ water depth can reach a maximum of $45 \mathrm{~cm} / \mathrm{s}$ also with a longitudinal northward component (Noernberg \& Alberti 2014). Bottom currents and wave energy can easily overcome sediment displacement threshold.

Another example of sediments outcropping in stratigraphic windows is the German Bight continental shelf. Mud occurs in troughs of sand ridges with coarse sands and fine gravels. The action of storm waves is responsible for the exposure and rework of coarse sands and fine gravels, characterized as Pleistocene palimpsests deposits, and fine sediments, described as early Holocene estuarine mud (Son et al. 2012). Similarly, in the PICS medium to coarse sands and muddy facies occur related with sand ridges. There are no obvious sources capable of delivering coarse sediments to the continental shelf at present. Therefore, these sediments could only be relict or palimpsest. Muddy facies apparently concentrate in sand-ridges troughs from the shoreface until $20 \mathrm{~m}$ water depth while medium to coarse sand concentrate on ridges crests up to $30 \mathrm{~m}$ water depth. Sediments eroded from seacliffs downward of longshore currents feed the Algarve inner continental shelf (Rosa et al. 2013). Similarly, the most likely sand source to the PICS may be the sediments eroded from coastal plains located southward. As noted before by Lessa et al. (2000), Paraná coast might be fed by sediments provided by the erosion of coastal barriers at the northern end the Santa Catarina State. As bottom 
longshore currents at the region flow northward (Noernberg \& Alberti 2014), sediment transport path must follow the same direction. However, this should be restricted to the immediate vicinity of the coast and perhaps to the migration of sand ridges.

Other evidence of outcropping paleoenvironments in the PICS are the sandstones bodies described by Simioni (2011). At $33 \mathrm{~m}$ water depth, sandstone composed exclusively of blocky drusy form, microcrystalline and bladed calcite might be the result of calcite precipitation in a freshwater environment. Methane-related carbonate cement in sandstones between 18 and $29 \mathrm{~m}$ water depth presents characteristics of cementation in the transitional marinephreatic environment. In both cases, the processes of cementation occur at subsurface, and thus they are representative of paleoenvironments outcropping at the PICS surface. Moreover, the methane prompted cementation requires large quantities of organic matter lying under a relatively thick layer of sediments (Roberts \& Whelan 1975, Hovland et al. 1987, Han et al. 2008). That is consistent with the speculation of underlying or outcropping of organic-matter-rich muddy sediments at the PICS.

A more detailed investigation is needed, on the evolution of Superagüi and Guaratuba barriers, and on the contribution of fine sediments from local estuaries to the inner continental shelf, to answer the question: if fine sediments have their origin related with outcrops of transgressive muds or with modern estuarine input. Possibly both processes may be contemporaneous. Wave action may fluidize the ancient outcropping mud. Fluidized muds, in turn, may promote waves attenuation and consequently better conditions to recent fine sediments provided by estuaries to settle and remain in shallow regions of the inner continental shelf.

\section{Conclusions}

The PICS morphology and sediment distribution are not homogeneous. The slope is gentle, and there is a low gradient overall, but it can reach up to $0.35^{\circ}$. Two kinds of sediment heterogeneity were found, one associated with sand ridges fields and other with muddy sediments.

The disposal of sediments in the PICS differs significantly from classic models based on decreasing grain size seaward, the offshore transition zone is wider, and its outer limit is deeper than worldwide. The differences are due mainly to the presence of relict or palimpsests, medium to coarse sands, between 10 and $30 \mathrm{~m}$ and muddy sediments, between 5 and $15 \mathrm{~m}$ water depth. Sediments mean diameters at the shoreface are relatively lower, $0.063-0.125 \mathrm{~mm}$, than in deeper regions of the inner continental shelf, where fine sand predominate and coarse, and medium sands may occur.

The analysis of grain-size distribution curves proved to be efficient to distinguish sediment patterns and facies. Grain-size curves of very fine sands are different in the shoreface and deeper inner continental shelf areas.
Sediment input is nearly null or ultimately restricted to fine-grained sediments delivered by estuarine discharge and sand size sediments that eventually escapes by the main channel of the estuaries or rivers that discharge directly into the continental shelf. Other sediments seemed to be deposited before the Holocene highstand sea level. In comparison to other continental shelf environments in which fine-grained sediments input is ongoing, the PICS muds are related to the presence of depressions in a high-energy environment associated with shoreface-connected sand ridges. These muds may be new sediments provided by adjacent estuaries. However, if hydrodynamic processes can rework sediments earlier deposited, then sediment remobilization might be excavating the bed wherein older sediments deposits are outcropping. In this case, where sediment starvation takes place, paleoenvironments can act as sediment sources to low gradient, wide and sediment starved inner continental shelves.

Sediments distribution coastward follows a pattern over the studied area. First, there is a prevalence of sand in the inner continental shelf sands from 10 to $30 \mathrm{~m}$ deep. In this region, isolated areas of relict or palimpsest sediments occur, with the mean grain size between the medium and coarse sand. In the shoreface, associations of very fine sand enriched with mud in the lower shoreface and of muddy sediments in the middle shoreface predominate. In the upper region of the inner continental shelf limited by the surf zone, associations of well-sorted fine to very fine sands, typical of highenergy environments, occur. Studies and models of beach morphodynamics, wave propagation, coastal intervention, sediment transport models and shoreline changes should take into account the spatial distribution and heterogeneity of the inner continental shelf sediments to avoid misinterpretations of their results.

We suggest that the PICS is not only receiving low amounts of sediments but also it has been eroded acting as a source to adjacent sandy beaches. The estuarine complexes of the region may supply fine-grained sediments to the inner continental shelf. However, an underlying paleo-estuarine layer might be outcropping mainly at Guaratuba and Superagüi sectors. Further studies should be carried out to elucidate these issues.

\section{Acknowledgments}

We gratefully acknowledge the Comissão Interministerial para Recursos do Mar (CIRM) and the Programa de Geologia e Geofísica Marinha (PGGM) for their support trough the Programa de Avaliação da Potencialidade Mineral da Plataforma Continental Jurídica Brasileira - REMPLAC/Score Sul, the crew of NPq. Soloncy Moura and NOc. Atlântico Sul for their assistance with fieldwork. LHS, RJA, MCS and FAV were sponsored by $\mathrm{CNPq}$ scholarships. RJA was sponsored by the Fundação Araucária with a senior scholarship and LHS was sponsored by CNPq with a technical fellowship 382303/2008-3 and a doctoral fellowship 1815/2012-4. This study was supported by 
CNPq projects 558781/2008-0, 471668/2008-7, 477945/2012-0 and by Fundação Araucária project P$6039 / \mathrm{C}-018 / 2005$. We also would like to thank the anonymous reviewers for their valuable comments and considerations in improving the quality of the manuscript.

\section{References}

Angulo R.J. 1992. Geologia da planície costeira do Estado do Paraná. Tese de Doutorado, Pós-graduação em Geologia Sedimentar, Universidade de São Paulo, 334p.

Angulo R.J., Araújo A.D. 1996. Classificação da Costa Paranaense com base na sua dinâmica como subsídio à ocupação da orla litorânea. Boletim Paranaense de Geociências, 44:7-17.

Angulo R.J. 2000. As praias do Paraná: problemas decorrentes de uma ocupação inadequada. Revista Paranaense de Desenvolvimento, 99:97-103.

Angulo R.J., Soares C.R., Marone E., Souza M.C., Odreski L.L.R., Noernberg M.A. 2006. Paraná. In: Muehe D. (org) Erosão e progradação do litoral brasileiro. Ministerio do Meio Ambiente, Brasília, 347-400p.

Angulo R.J., Lessa G.C., Souza M.C., 2009. The Holocene barrier systems of Paranaguá and northern Santa Catarina coasts, Southern Brazil. In: Dillenburg S.R., Hesp P.A. (org) Geology and geomorphology of Holocene coastal barriers of Brazil, Lecture Notes in Earth Sciences. Springer-Verlag, Berlin, 107:135-176

Angulo R.J., Borzone C.A., Noernberg M.A., Quadros C.J.L., Souza M.C., Rosa L.C. 2016. The State of Paraná Beaches. In: Short A.D., Klein A.H.F. (org) Brazilian beach systems. Springer, Switzerland, 419-464.

Anthony E.J. 2015. Wave influence in the construction, shaping and destruction of river deltas: A review. Marine Geology, 361:53-78.

Blott S.J., Pye K. 2001. GRADISTAT: a grain size distribution and statistics package for the analysis of unconsolidated sediments. Earth Surface Processes and Landforms, 26(11):1237-1248.

Calliari L.J., Speranski N.S., Torronteguy M., Oliveira M.B., 2001. The mud banks of Cassino Beach, southern Brazil: characteristics, processes and effects. Journal of Coastal Research, Special Issue 34:318-325.

Calliari L.J., Holland K.T., Pereira P.S., Guedes R.M., Santo R.E. 2007. The influence of mud on the inner shelf, shoreface, beach, and surf zone morphodynamics - Cassino, Southern Brazil. In: Coastal Sediments' 07, 1455-1465.

Carver R.E., 1971. Procedures in sedimentary petrology, WileyInterscience, New York, 653p.

Chou H.T., Hunt J.R., Foda M.A., 1991. Fluidization of marine mud by waves. Marine Pollution Bulletin, 23:75-81.

Coleman J.M., Roberts H.H., Stone G.W., 1998. Mississippi River delta: an overview. Journal of Coastal Research, 14(3):699-716.

Crockett J.S., Nittrouer C.A., 2004. The sandy inner shelf as a repository for muddy sediment: an example from Northern California. Continental Shelf Research, 24(1):55-73.

Davies B.E., 1974. Loss-on-ignition as an estimate of soil organic matter. Soil Science Society of America Journal, 38(1):150-151.

DeMaster D.J., McKee B.A., Nittrouer C.A., Jiangchu Q., Guodong C. 1985. Rates of sediment accumulation and particle reworking based on radiochemical measurements from continental shelf deposits in the East China Sea. Continental Shelf Research, 4(1):143-158.

Dominguez J.M.L., da Silva R.P., Nunes A.S., Freire A.F.M. 2013 The narrow, shallow, low-accommodation shelf of central Brazil: sedimentology, evolution, and human uses. Geomorphology, 203:46-59.

Figueiredo A.G., Tessler M.G. 2004. Topografia e composição do substrato marinho da região Sudeste-Sul do Brasil. São Paulo. Instituto Oceanográfico da Universidade de São Paulo, Série Documentos REVIZEE: Score Sul, 64p.

Folk R.L., Ward W.C. 1957. Brazos River bar: a study in the significance of grain size parameters. Journal of Sedimentary Research, 27(1):3-27.

Folk R.L. 1965. Petrology of sedimentary rocks. Hemphill Publishing Company, Austin, 184p.
Franke R., 1982. Smooth interpolation of scattered data by local thin plate splines. Computers \& Mathematics with Applications, 8(4):273-281.

Han X., Suess E., Huang Y., Wu N., Bohrmann G., Su X., Eisenhauer A., Rehder G., Fang Y. 2008. Jiulong methane reef: microbial mediation of seep carbonates in the South China Sea. Marine Geology, 249(3):243-256.

Holland K.T., Elmore P.A. 2008. A review of heterogeneous sediments in coastal environments. Earth-Science Reviews, 89(3):116-134.

Hovland M., Talbot M.R., Qvale H., Olaussen S., Aasberg L. 1987. Methane-related carbonate cements in pockmarks of the North Sea. Journal of Sedimentary Research, 57(5):881:892.

Johnson D.W. 1919. Shore Processes and Shoreline Development. John Wiley \& Sons, New York, 584p.

Lessa G.C., Angulo R.J., Giannini P.C., Araújo A.D. 2000. Stratigraphy and Holocene evolution of a regressive barrier in south Brazil. Marine Geology, 165(1):87-108.

Mahiques M.M.D., Sousa S.H.D.M., Furtado V.V., Tessler M.G., Toledo F.A.D.L., Burone L., Figueira R.C.L., Klein D.A., Martins C.C., Alves D.P.V. 2010. The Southern Brazilian shelf: general characteristics, quaternary evolution and sediment distribution. Brazilian Journal of Oceanography, 58:25-34.

Marone E., Jamayanaa D. 1997. Tidal characteristics and a variable boundary numerical model for the M2 tide for the estuarine complex of the Bay of Paranaguá, PR, Brazil. Nerítica, 11(12):95-107.

Masselink, G., Lessa, G., 1995. Barrier stratigraphy on the macrotidal central Queensland coastline, Australia. Journal of Coastal Research, 11(2):454-477.

Mayerle R., Narayanan R., Etri T., Wahab A.K.A. 2015. A case study of sediment transport in the Paranagua Estuary Complex in Brazil. Ocean Engineering, 106:161-174.

McManus D.A. 1975. Modern versus Relict sediments on continental shelf. Geological Society of America Bulletin, 86:1154-1160.

Milliman J. D. 1974. Marine carbonates. Springer, New York, 375p.

Milliman J. D., Barreto H. T. 1975 Background. Upper continental margin sedimentation off Brazil. Contributions to Sedimentology, 4:1-10.

Nemes D.D., Marone E. 2013. Caracterização das ondas de superfície na plataforma interna do Estado do Paraná, Brasil. Boletim Paranaense de Geociências, 68:12-25.

Noernberg M.A. Marone E., Angulo R.J. 2007. Coastal currents and sediment transport in Paranaguá estuary complex navigation channel. Boletim Paranaense de Geociências, 60(61):45-54.

Noernberg M.A., Alberti A.L. 2014. Oceanographic variability in the inner shelf of Paraná, Brazil: spring condition. Revista Brasileira de Geofísica, 32(2):197-206.

Pianca C., Mazzini P.L.F., Siegle E. 2010. Brazilian offshore wave climate based on NWW3 reanalysis. Brazilian Journal of Oceanography, 58(1):53-70.

Quadros C.J.L., Marone E., Angulo R.J., Martins G.J., Netto Jr J.P.B. 2007. Dinâmica morfosedimentar associada à incidência de sistemas frontais em duas praias do litoral paranaense. Boletim Paranaense de Geociências, 60:65-74.

Roberts H.H., Whelan T. 1975. Methane-derived carbonate cements in barrier and beach sands of a subtropical delta complex. Geochimica et Cosmochimica Acta, 39(8):1085-1089.

Rosa F., Rufino M.M., Ferreira Ó., Matias A., Brito A.C., Gaspar M.B., 2013. The influence of coastal processes on inner shelf sediment distribution: The Eastern Algarve Shelf (Southern Portugal). Geologica Acta, 11(1):59-73.

Sheremet A., Mehta A.J., Liu B., Stone G.W. 2005. Wave-sediment interaction on a muddy inner shelf during Hurricane Claudette. Estuarine, Coastal and Shelf Science, 63(1):225-233.

Sielski L.H. 2015. Morfologia e sedimentologia da plataforma continental interna paranaense. Tese de Doutorado, Pósgraduação em Geologia, Universidade Federal do Paraná, 86p.

Simioni B.I. 2011. Arenitos submersos do litoral paranaense e sua implicação no estudo de paleoníveis marinhos. Dissertação de Mestrado, Pós-Graduação em Geologia, Universidade Federal do Paraná, 67p.

Son C.S., Flemming B.W., Chang T.S. 2012. Sedimentary facies of shoreface-connected sand ridges off the East Frisian barrier island coast, southern North Sea: climatic controls and preservation potential. In: Li M., King E.L., Prescott R.H. (eds) Sediments, 
Morphology and Sedimentary Processes on Continental Shelves. International Association of Sedimentologists, Special Publication, 44:143-158.

Souza M.C., Angulo R.J., Assine M.L., Castro D.L. 2012. Sequence of facies at a Holocene storm-dominated regressive barrier at Praia de Leste, southern Brazil. Marine Geology, 291:49-62.

Suter R.J., 2006. Facies Models Revisited: Clastic Shelves. in Posamentier H.W, Walker R.G. (eds) Facies Models Revisited. Society for Sedimentary Geology, Special Publication, 84:339397.

Veiga F.A., Angulo R.J, Marone E., Brandini F.P. 2004 Características sedimentológicas da plataforma continental interna rasa na porção central do litoral paranaense. Boletim Paranaense de Geociências, 55:67-75.

Veiga F.A., Angulo R.J., Sá F., Odreski L.L.R., Lamour M.R., Disaró S.T. 2006 Origin of mud deposits in a wave dominated shallow inner continental shelf of the State of Paraná coast, southern Brazil. Journal of Coastal Research, Special Issue, 39:262-265.

Walsh J.P., Nittrouer C.A., 2009. Understanding fine-grained riversediment dispersal on continental margins. Marine Geology, 263(1):34-45.

Wentworth C.K. 1922. A scale of grade and class terms for clastic sediments. Journal of Geology, 30(5):377-392.

Wright L.D. 1995. Morphodynamics of inner continental shelves. CRC Press, Boca Raton, 241p.

Wright L.D., 2012 Recent advances in understanding continental shelf sediment transport. In: Li M., King E.L., Prescott R.H. (eds) Sediments, Morphology and Sedimentary Processes on Continental Shelves. International Association of Sedimentologists, Special Publication, 44:159-172.

Xu D.L., Lu H., Yu D. 1999. On the relationships between the mean wavelength and wave-period of wind waves in deep water. Applied Ocean Research, 21(3):127-131.

Zembruscki S.G. 1979. Geomorfologia da margem continental sul brasileira e das bacias oceânicas adjacentes. Série Projeto REMAC, Petrobras - CENPES - DINTEP, 7: 129-177.

Recebido 11 de maio de 2017 Aceito 19 de outubro de 2017 